\title{
Examining Relationships between Education Abroad Program Design and College Students' Global Learning
}

\author{
Tara D. Hudson \\ Kent State University \\ Rachel Tomás Morgan \\ University of Notre Dame
}

\begin{abstract}
:
Education abroad is a high-impact practice that can lead to transformational learning because it challenges students emotionally and intellectually. However, differences in program design may have differential impacts on students' learning. The purpose of this study was to understand the relationships between design features of education abroad programs - specifically, program duration and the extent of students' engagement in learning and with local communities while abroad-and participants' pre-test to post-test growth in global learning, measured via the nationally validated Global Perspective Inventory survey. Using structural equation models, we found program duration and frequency of engagement in certain learning and engagement abroad to have positive effects on participants' growth, although the relationships varied depending on the dimension of global perspective being measured. Nonetheless, our results provide further support for the need to intentionally design education abroad programs that facilitate deep learning and community interaction in order to ensure student learning.
\end{abstract}

\section{Introduction}

Both the Association of American Colleges and Universities (AAC\&U) and the National Survey of Student Engagement (NSSE) identify education abroad as a high-impact practice because of its powerful effect on college students' learning and development (Kuh, 2008; NSSE, 2007). The power of education abroad derives from its unique ability "to present participants with a challenge-the emotional and intellectual challenge of direct, authentic cultural encounters and guided reflection upon those encounters" (Engle \& Engle, 2003, pp. 6-7). In addition, as a form of experiential learning, education abroad presents students with complex, "messy" problems that are not usually encountered in classroom environments (Kuh, 2008).

Because education abroad challenges students both emotionally and intellectually, it is especially effective at facilitating holistic development (Gillespie et al., 2010), transformational learning (Selby, 2008), and deep learning (Kuh, 2008) for participating students. Research on student outcomes of education abroad has documented positive effects on essential learning outcomes, including civic values and engagement (Lott, 2013; Murphy et al., 2014; Tarrant et al., 2015), intercultural and global competence/understanding (Anderson \& Lawton, 2011; Engberg, 2013; Heinzmann et al., 2015; 
Kilgo et al., 2015; Kurt et al., 2013; Sutton \& Rubin, 2004; Tarrant et al., 2015; Trooboff et al., 20072008; Vande Berg, Paige, \& Lou, 2012), and intrapersonal development (Dwyer, 2004; Engberg, 2013; Tarrant et al., 2015).

However, much of the existing research examining the effects of education abroad on student learning and development has treated education abroad participation as a dichotomous variable, thereby assuming that program design elements such as duration, opportunities for reflection, and degree of engagement in the local community are unrelated to student learning gains (Engberg, 2013; Engle \& Engle, 2003). In one of a small number of studies examining the effects of program elements, Pederson (2010) found that the only group of students showing pre-test to post-test gains on the Intercultural Development Inventory (a measure of intercultural competence) were those in "a course which integrated intercultural effectiveness and diversity training pedagogy including cultural immersion, guided reflection, and intercultural coaching" (p. 70); students who studied abroad in a program without this intervention did not show gains (nor did a control group of students who did not study abroad). Similarly, two studies found positive relationships for program elements including engaging in assignments involving the community, speaking the host language in and out of class, and classroom reflective assignments with participants' development of intercultural wonderment, a concept measuring study abroad participants' curiosity and tolerance of discomfort for new experiences (Engberg \& Jourian, 2015; Engberg, Jourian, \& Davidson, 2016). Two studies have found a positive relationship between participation in service learning and global learning; although these studies examined domestic service learning, not study abroad, they provide support for the idea that community engagement enhances intercultural learning (Engberg, Davidson, Manderino, \& Jourian, 2016; Engberg \& Fox, 2011). A somewhat larger number of studies have examined the effect of program length on participants' learning and development, but results have been inconsistent; some conclude short-term programs are ineffective for student learning (Hoff, 2008; Medina-Lopez-Portillo, 2004; Vande Berg, Connor-Linton, \& Paige, 2009), while others provide evidence that even short term-programs can lead to learning gains (Fine \& McNamara, 2011; Gaia, 2015; Kurt, Olitsky, \& Geis, 2013; Selby, 2008).

Stebleton, Soria, and Cherney (2013) hypothesize that the primary reason why "formal study abroad opportunities" (as compared to recreational travel or informal educational opportunities abroad) lead to student learning gains is "a direct result of the intentionality and structured planning behind well-designed study abroad programs" (p. 15). In other words, not all education abroad programs are equally effective in fostering student learning and development, and as a result, there is a need for research to examine "the potential differential effects of study abroad across the array of programmatic differences that currently exist" (Salisbury et al., 2013, p. 15). The purpose of the present study was to understand the relationships between features of education abroad programsspecifically, program duration and the extent of students' engagement in learning and with local communities while abroad-and participants' growth on one particular learning outcome, global perspective.

\section{Conceptual Framework}

This research is situated within the ample body of scholarship documenting the student learning and development fostered by education abroad. As a high-impact educational practice (Kuh, 2008), education abroad facilitates growth in many, if not all, of the areas identified by the 
AAC\&U as essential learning outcomes of a college education "that all students need for success in work, citizenship, and life" (AAC\&U, 2017, p. 7). Two of these are especially (although not exclusively) relevant to education abroad (Bennett, 2008): (1) intercultural knowledge competence, defined as "a set of cognitive, affective, and behavioral skills and characteristics that support effective and appropriate interaction in a variety of cultural contexts" (Bennett, 2008, cited in AAC\&U, n.d., p. 17) and (2) global learning, defined as "a critical analysis of and an engagement with complex, interdependent global systems and legacies (such as natural, physical, social, cultural, economic, and political) and their implications for people's lives and the earth's sustainability" (AAC\&U, n.d., p. 9).

Elements of both intercultural knowledge competence and global learning are reflected in the concept of global perspective, which is the learning and development outcome of focus for this study. As described by Chickering and Braskamp (2009):

Having students develop a global perspective means helping them develop the capacity to think with complexity, taking into account multiple cultural perspectives. They need to form a unique sense of self that is authentic and consistent with their own cultural background, and to relate to others who differ with respect and openness. Developing a global perspective stresses personal and social responsibility that is based on interdependence, identity, purpose, and emotional intelligence. (p. 28)

Like other holistic models of development, global perspective accounts for development along cognitive, intrapersonal, and interpersonal dimensions (Merrill et al., 2012). It "includes acquisition of knowledge, attitudes, and skills important to intercultural communication and holistic development of more complex epistemological processes, identities, and interpersonal relations as described by educational scholars" (Merrill et al., 2012, p. 356). Although global perspective is similar to concepts such as intercultural competence, its theoretical foundations make it a conceptually distinct construct (Braskamp, Braskamp, \& Engberg, 2014). Additionally, an empirical comparison of the Intercultural Development Inventory, designed to measure intercultural sensitivity, and the Global Perspective Inventory, which measures global perspective, found correlations between scores on the two instruments to be small, leading the authors to conclude that the two instruments "measure different dimensions of intercultural development" (Anderson \& Lawton, 2011, p. 97).

Empirical research has documented the positive effects of education abroad on global perspective, as measured via the Global Perspective Inventory (GPI), a nationally validated instrument (see Braskamp et al., 2014; Chickering \& Braskamp, 2009; Merrill et al., 2012; RISE, 2017). The GPI measures three dimensions of global perspective development: "how students think (cognitive), how they view themselves (intrapersonal), and how they relate to others who are different (interpersonal)" (RISE, 2017, p. 7). Participating in education abroad has been found to increase students' post-test GPI scores; generally, effects have been found to be strongest for the cognitive and interpersonal dimensions and weaker for the intrapersonal dimension (Braskamp et al., 2014; Engberg, 2013; Merrill et al., 2012; Tarrant et al., 2015).

However, while education abroad generally has a positive effect on student learning and development outcomes - including global perspective as well as intercultural competence and related outcomes-features of program design as well as the experiences that students have while abroad 
can moderate or mediate students' learning. Some of the most frequently examined mediating factors - what researchers of intercultural learning such as Vande Berg, Paige, and Lou (2012) would call intercultural interventions - include program duration, engagement in local communities (e.g., through service learning, volunteering, or internships), other forms of intercultural contact (whether through structured program experiences or pursued by students on their own), living arrangement, use of target language, cultural mentoring, and reflection opportunities (Engle \& Engle, 2003; Heinzmann et al., 2015; Hoff, 2008; Vande Berg, Connor-Linton, \& Paige, 2009; Vande Berg, Paige, \& Lou, 2012). Because it is difficult (if not impossible) to isolate the effects on student learning of any single program feature or experience through experimental or even quasi-experimental methods, results of prior research are inconsistent.

For example, some studies included in a literature review by Hoff (2008) showed that shortterm experiences (e.g., a summer or a month) did not yield learning outcomes (see also MedinaLopez-Portillo, 2004; Vande Berg, Connor-Linton, \& Paige, 2009). In contrast, Kurt, Olitsky, and Geis (2013) found that short-term education abroad "programs provide the same benefits as longer duration programs; however, the magnitude of these benefits may be muted" (p. 23). Selby (2008) provides some nuance, arguing that program duration is correlated with student learning because "the more time students are immersed in another culture, the more time they have to figure things out for themselves through random experience and local feedback" (p. 8), yet shorter programs can nonetheless provide transformative learning experiences for students if they provide sufficient structure before, during, and after the immersion abroad to ensure students achieve the intended learning. Alternatively, Heinzmann, Künzle, Schallhart, and Müller (2015) posit that the relationship between program duration and learning is a U-shaped development curve, with students initially having positive attitudes, then encountering challenges to those attitudes (disequilibrium), then reconciling those attitudes. Their findings suggest that "medium-length" programs (which they do not clearly define) predict the greatest gains in intercultural competence.

Research results are more consistent for the effects of intercultural contact and engagement experiences on student learning, although the frequency, depth, and conditions of the contact/experiences may lead to greater or lesser learning (Deardorff, 2008; Heinzmann et al., 2015; Medina-Lopez-Portillo, 2004; Vande Berg, Connor-Linton, \& Paige, 2009; Vande Berg, Paige, \& Lou, 2012; but see Pederson, 2010, for conflicting evidence). Research has also determined that inclusion of guided reflection opportunities facilitates learning by helping students make meaning of their experiences (Bennett, 2008; Deardorff, 2008; Dixon, 2015; Engle \& Engle, 2003; Hoff, 2008; Kiely, 2004; Pederson, 2010).

The present study is informed by these prior research findings establishing the need for interventions within study abroad that enhance students' intercultural competence. The conceptual model for this study investigates the relationships between education abroad program design features (specifically, engagement experiences and program duration) and students' development of global perspective. Our conceptual model is also informed by Astin's (1993) I-E-O (InputsEnvironment-Outputs) model insofar as recognizing that students' experiences prior to participating in an education abroad program shape how they experience their learning environments as well as the ultimate learning outcomes of those environments. 


\section{Methodology}

\section{Data Collection and Participants}

This study was conducted at a medium-sized Catholic university located in the Midwestern United States. Approval was obtained from the university's Institutional Review Board prior to beginning the study, and all participants provided informed consent. All students at the university who participated in education abroad in 2012 or 2013 through either a semester-long education abroad program or an international summer service-learning program offered by the university were invited to participate in the study. Semester-long programs occurred mainly in European contexts, with the exception of Chile and Mexico. For the programs in Europe, there was little to no predeparture preparation that included cultural content and no re-entry sessions. The programs in Chile and Mexico included significant service learning and internship opportunities, students lived with families in homestay placements, and there were pre-departure and re-entry sessions with cultural and global learning content structured into the program design. The international summer servicelearning programs included a semester-long pre-departure course and a six-week re-entry course that bookended the eight- to ten-week service-learning placements with local organizations. Students are paired and deployed to work with community-based organizations in Latin America (Argentina, Bolivia, Brazil, Ecuador, El Salvador, Guatemala, Honduras, Nicaragua, Peru), Africa (Ghana, Senegal, South Africa, Tanzania, Uganda), and Asia (Bangladesh, Cambodia, India, Nepal). These programs included structured and guided reflection prior to, during, and after immersion, and students lived with locals on the site of the local organization or in homestay settings. Table 1 provides the number and percentage of participants experiencing four program elements (program duration, English spoken while abroad, living with a host family, and internship or service learning), by program type.

Table 1. Number and percentage of participants experiencing program features, by program type. Education Abroad Program Features

\begin{tabular}{llll} 
Program Type & $\begin{array}{l}\text { English } \\
\text { Spoken }\end{array}$ & $\begin{array}{l}\text { Lived with } \\
\text { Host Family }\end{array}$ & $\begin{array}{l}\text { Internship or Service } \\
\text { Learning }\end{array}$ \\
\hline $\begin{array}{l}\text { International summer service-learning } \\
\text { program } \\
(\mathrm{n}=101)\end{array}$ & $23(23 \%)$ & $40(40 \%)$ & $92(91 \%)$ \\
$\begin{array}{l}\text { Semester-long program } \\
(\mathrm{n}=106)\end{array}$ & $56(53 \%)$ & $38(35 \%)$ & $46(43 \%)$ \\
\hline
\end{tabular}

The survey instrument used to collect data was the Global Perspective Inventory (GPI). First administered in 2007, the GPI has been used by nearly 200 educational institutions to date (RISE, 2017). The GPI includes two scales, "one scale reflect[ing] cultural development theory and the other reflect[ing] intercultural communication theory" (RISE, 2017, p. 7), for each of the three dimensions of global perspective (cognitive, intrapersonal, and interpersonal):

1. Cognitive - Knowledge: "Respondents' levels of confidence regarding what they know regarding other cultures" (Merrill et al., 2012, p. 357)

2. Cognitive - Knowing: Respondents' recognition of "the importance of cultural context in judging what is important to know and value" (RISE, 2017, p. 8) 
3. Intrapersonal - Affect: "Respondents' acquisition of emotional comfort (including selfconfidence) with situations that are different from or challenge their own cultural norms" (Merrill et al., 2012, p. 357) as well as "level of respect and acceptance of cultural perspectives different from one's own” (Global Perspective Institute, n.d.)

4. Intrapersonal - Identity: Respondents' sense of their own identity, purpose, and cultural background (Merrill et al., 2012)

5. Interpersonal - Social Interactions: Respondents' engagement with others from different cultural backgrounds and cultural sensitivity (Merrill et al., 2012; RISE, 2017)

6. Interpersonal - Social Responsibility: Respondents' "level of commitment to interdependent living and the common good” (Merrill et al., 2012, p. 358)

Each of the six scales was measured by a series of items using a 5-point Likert scale ranging from 5 (strongly agree) to 1 (strongly disagree). Some items were reverse-coded prior to calculating scale scores. Reported national aggregate test-retest reliabilities for the six GPI scales range from 0.49 to 0.81 (for version 3 of the instrument), and national alphas for each of the six scales (for version 9) range from a low of 0.657 for Cognitive - Knowing to a high of 0.773 for Cognitive Knowledge (Braskamp et al., 2014).

We contracted with the Global Perspective Institute (owners of the GPI) to collect all data for this study. Researchers at the university invited potential participants by email, including links provided by the Global Perspective Institute to complete the pre-test and post-test surveys online. The Institute returned the raw data to the researchers in an Excel spreadsheet. Pre-test data for both 2012 and 2013 was collected using General Form V7 of the GPI, which participants completed during the pre-departure stage. Post-test data was collected using Study Abroad Form V8 in 2012 and Study Abroad Form V9 in 2013. Participants completed the pre-test prior to departure and the post-test after their return to the US. In 2012, 207 students participated, and of these, 103 (49.8\%) completed both pre-test and post-test. In 2013, 190 students participated, and of these, 104 (54.7\%) completed both pre-test and post-test. For the analyses presented here, we retained only those cases for which both pre-test and post-test scores were available, and to ensure adequate sample size for analyses, we combined samples from both study years (2012 and 2013) and both types of programs (traditional and international summer service-learning). Two students participated in both 2012 and 2013; only their 2012 data was retained for analyses, and this is reflected in the participation numbers previously provided. The total analytic sample size therefore consists of 207 responses. Table 2 provides descriptive characteristics of the analytic sample. 
Table 2. Descriptive statistics of the analytic sample $(n=207)$.

\begin{tabular}{|c|c|c|}
\hline Variable $^{1}$ & $\mathbf{N}$ & $\%$ \\
\hline \multicolumn{3}{|l|}{ Demographics } \\
\hline \multicolumn{3}{|l|}{ Gender } \\
\hline Male & 86 & $41.6 \%$ \\
\hline Female & 120 & $58.0 \%$ \\
\hline Other Gender Identity & 1 & $0.5 \%$ \\
\hline \multicolumn{3}{|l|}{ Ethnicity } \\
\hline Student of Color & 44 & $21.3 \%$ \\
\hline European/White & 161 & $77.8 \%$ \\
\hline Not Reported & 2 & $1.0 \%$ \\
\hline \multicolumn{3}{|l|}{ International Student } \\
\hline Yes & 10 & $4.8 \%$ \\
\hline No & 196 & $94.7 \%$ \\
\hline Not Reported & 1 & $0.5 \%$ \\
\hline \multicolumn{3}{|l|}{ College Experiences } \\
\hline \multicolumn{3}{|l|}{ Year in College } \\
\hline First Year & 5 & $2.4 \% \%$ \\
\hline Sophomore & 50 & $24.2 \%$ \\
\hline Junior & 150 & $72.5 \%$ \\
\hline Senior & 1 & $0.5 \%$ \\
\hline Graduate Student & 1 & $0.5 \%$ \\
\hline \multicolumn{3}{|l|}{ Major } \\
\hline Arts \& Humanities & 55 & $26.6 \%$ \\
\hline Business & 43 & $20.8 \%$ \\
\hline Social Sciences & 38 & $18.4 \%$ \\
\hline STEM & 68 & $32.9 \%$ \\
\hline Not Reported & 3 & $1.5 \%$ \\
\hline \multicolumn{3}{|l|}{ College GPA } \\
\hline A & 133 & $64.3 \%$ \\
\hline $\mathrm{B}$ & 72 & $34.8 \%$ \\
\hline $\mathrm{C}$ & 2 & $1.0 \%$ \\
\hline \multicolumn{3}{|l|}{ Prior Study Abroad } \\
\hline Yes & 53 & $25.6 \%$ \\
\hline No & 154 & $74.4 \%$ \\
\hline
\end{tabular}


Table 2 continued

\begin{tabular}{lll}
\hline Variable $^{\mathbf{1}}$ & $\mathbf{N}$ & $\mathbf{\%}$ \\
\hline Education Abroad Program Features & & \\
Program Duration & & \\
2 Terms & 3 & $1.5 \%$ \\
1 Term & 110 & $53.1 \%$ \\
Short Term (<1 Term) & 94 & $45.4 \%$ \\
English Spoken & & \\
Yes & 79 & $38.2 \%$ \\
No & 128 & $61.8 \%$ \\
Lived with Host Family & & \\
Yes & 76 & $36.7 \%$ \\
No & 131 & $63.3 \%$ \\
Internship or Service Learning Participation & & \\
Yes & 135 & $65.2 \%$ \\
No & 72 & $34.8 \%$ \\
\hline
\end{tabular}

${ }^{1}$ All variables reported here were measured at pre-test, excepting those pertaining to the features of the education abroad program.

Some of the items included on the post-test forms differed between the 2012 and 2013 versions, affecting items used to calculate three of the six global perspective scales. The affected scales were Intrapersonal - Identity (one item different between years), Intrapersonal - Affect (five items), and Interpersonal - Social Interactions (five items). The large difference between items used to calculate the 2012 and 2013 Intrapersonal - Affect and Interpersonal - Social Interactions scales made it impossible to compare scores across sample years, so we chose not to use these two scales in our analyses. Because the Intrapersonal - Identity scale only differed by one item between years, we chose to create an adapted version of that scale using the items that appeared on the both the 2012 and 2013 post-tests; therefore, our alpha for this adapted scale cannot be compared to the national alpha. Items used to calculate the remaining three scales (Cognitive - Knowing, Cognitive Knowledge, and Interpersonal - Social Responsibility) did not change from 2012 to 2013. Table 3 lists descriptive statistics and sample items for each of the four global perspective scales used in this study. 
Table 3. Descriptive statistics ${ }^{1}$ and sample items for global perspective scales.

\begin{tabular}{|c|c|c|c|c|c|c|c|c|c|c|}
\hline Scale & Sample Item & $\begin{array}{l}\# \text { of } \\
\text { Items }\end{array}$ & $\begin{array}{l}\text { Nation- } \\
\text { al } \\
\text { Alpha }{ }^{2}\end{array}$ & $\begin{array}{l}\text { Pre- } \\
\text { test } \\
\text { Alpha }\end{array}$ & $\begin{array}{l}\text { Post- } \\
\text { test } \\
\text { Alpha }\end{array}$ & $\begin{array}{l}\text { Pre- } \\
\text { test } \\
\text { Mean }\end{array}$ & $\begin{array}{l}\text { Pre- } \\
\text { test SD }\end{array}$ & $\begin{array}{l}\text { Post- } \\
\text { test } \\
\text { Mean }\end{array}$ & $\begin{array}{l}\text { Post- } \\
\text { test SD }\end{array}$ & $\begin{array}{l}\text { Pre- } \\
\text { Post } \\
\text { Change } \\
\text { Mean }\end{array}$ \\
\hline $\begin{array}{l}\text { Cognitive - } \\
\text { Knowing }\end{array}$ & $\begin{array}{l}\text { I rarely question } \\
\text { what I have been } \\
\text { taught about the } \\
\text { world around me. } \\
\text { (reverse scored) }\end{array}$ & 7 & 0.657 & 0.611 & 0.582 & 3.86 & 0.435 & 3.98 & 0.409 & 0.12 \\
\hline $\begin{array}{l}\text { Cognitive - } \\
\text { Knowledge }\end{array}$ & $\begin{array}{l}\text { I can discuss } \\
\text { cultural } \\
\text { differences from } \\
\text { an informed } \\
\text { perspective. }\end{array}$ & 5 & 0.773 & 0.777 & 0.735 & 3.42 & 0.621 & 3.75 & 0.500 & 0.33 \\
\hline $\begin{array}{l}\text { Intrapersonal } \\
\text { - Identity }\end{array}$ & $\begin{array}{l}\text { I put my beliefs } \\
\text { into action by } \\
\text { standing up for } \\
\text { my principles. }\end{array}$ & 7 & $0.740^{3}$ & 0.790 & 0.750 & 4.12 & 0.474 & 4.18 & 0.412 & 0.06 \\
\hline $\begin{array}{l}\text { Interpersonal } \\
\text { - Social } \\
\text { Responsibility }\end{array}$ & $\begin{array}{l}\text { I think of my life } \\
\text { in terms of giving } \\
\text { back to society. }\end{array}$ & 5 & 0.732 & 0.730 & 0.694 & 3.95 & 0.536 & 4.01 & 0.531 & 0.06 \\
\hline
\end{tabular}

${ }^{1}$ Non-standardized means and standard deviations are reported in this table. Means measured on a scale of 1 to 5. Standardized variables were used for analyses.

${ }^{2}$ Reported in Braskamp et al. (2014)

${ }^{3}$ Items used to calculate this scale for the present study differ slightly from items used nationally.

\section{Data Analysis}

The purpose of this study was to understand how two features of education abroad programs - engagement experiences and program duration-shape participants' growth in global perspective, as findings of previous studies examining the effect of these programmatic features/experiences on student learning have been inconclusive. Guided by the I-E-O model, we chose to use structural equation modeling (SEM) to analyze data as it allows for analysis of both direct and indirect effects on the outcome of interest. Figure 1 presents the conceptual model, with hypothesized relationships. Because we were interested in determining the effect, if any, of selected education abroad program design elements on students' pre-test to post-test growth on scores on the four GPI scales, the outcomes of interest were the change scores (i.e., difference between pretest and post-test scores) on each scale, rather than post-test scores.

Each model includes three exogenous variables. The first two, Intercultural Engagement and Current Events Engagement, represent latent constructs drawn from GPI pre-test items, constructed using the iterated principal factor method (the "factor" command with the "ipf factors" option in Stata). Intercultural Engagement is comprised of four items concerning frequency of 
intercultural interactions and participation in cultural events, each measured on a 5-point scale ranging from "never" to "very often." Current Events Engagement consists of four items addressing the extent of participants' interest in news and current events. We chose to include these two latent constructs as exogenous variables as we hypothesized that students' relative levels of intercultural engagement or engagement with current events may predict their pre-test scores on several of the global perspective scales. The third exogenous variable represents prior study abroad, measured by a single dichotomous item (yes or no).

Table 4. Descriptive statistics ${ }^{1}$ and sample items for latent constructs.

\begin{tabular}{|c|c|c|c|c|c|c|c|}
\hline Construct & Item & $\begin{array}{l}\# \text { of } \\
\text { Items }\end{array}$ & Alpha & Mean & SD & Min & $\operatorname{Max}$ \\
\hline $\begin{array}{l}\text { Intercultural } \\
\text { Engagement }\end{array}$ & $\begin{array}{l}\text { Since coming to college, how often have you: } \\
\text { Participated in events or activities sponsored by } \\
\text { groups reflecting your own cultural heritage } \\
\text { Participated in events or activities sponsored by } \\
\text { groups reflecting a cultural heritage different from } \\
\text { your own } \\
\text { Interacted with students from a country different from } \\
\text { your own } \\
\text { Interacted with students from a race/ethnic group } \\
\text { different from your own }\end{array}$ & 4 & 0.714 & 0 & 0.734 & -1.69 & 1.89 \\
\hline $\begin{array}{l}\text { Current } \\
\text { Events } \\
\text { Engagement }\end{array}$ & $\begin{array}{l}\text { Since coming to college, how often have you: } \\
\text { Read a newspaper or news magazine (online or in } \\
\text { print) } \\
\text { Watched news programs on television or computer } \\
\text { Followed an international event/crisis (e.g., through } \\
\text { newspaper, social media, or other media source) } \\
\text { Discussed current events with other students }\end{array}$ & 4 & 0.797 & 0 & 0.789 & -1.70 & 1.67 \\
\hline $\begin{array}{l}\text { Engagement } \\
\text { Abroad }\end{array}$ & $\begin{array}{l}\text { How often did/were you: } \\
\text { Interact with individuals from the host country } \\
\text { outside of the classroom } \\
\text { Reflect upon your experiences abroad through } \\
\text { writing/journaling as a part of course requirements } \\
\text { Feel immersed in the culture of the host country } \\
\text { Intentionally push yourself out of your comfort zone } \\
\text { Explore on your own new habits, behaviors, and } \\
\text { attitudes while studying abroad } \\
\text { Involved in a research project that required you to use } \\
\text { local resources during your study abroad (2012) or } \\
\text { Your class assignments require you to gather } \\
\text { information from your surrounding community } \\
\text { (2013) }\end{array}$ & 6 & 0.758 & 0 & 0.673 & -1.82 & 1.09 \\
\hline
\end{tabular}

${ }^{1}$ Standardized means and standard deviations are reported in this table. Standardized variables were used for analyses.

In addition, the analytic models include five endogenous variables. The first of these is pre-test score on the GPI scale of interest. The remaining four reflect education abroad program elements of interest: host family stay (dichotomous), program duration (dichotomous; 1 = one term or longer, $0=$ less than one term), participation in an internship or service-learning project 
(dichotomous), and Engagement Abroad, a latent construct consisting of six items asking students how often they engaged in certain learning and community interaction experiences while abroad, measured on a five-point scale ranging from "never" to "very often."

Table 4 presents descriptive statistics and constituent items for the three latent constructs included in analyses (Intercultural Engagement, Current Events Engagement, and Engagement Abroad). We standardized all non-dichotomous variables included in the models (for latent constructs, each component item score was standardized, and then the mean of the sum was calculated).

All analyses were conducted in Stata version 15, and we ran separate models for each of the four outcomes. Initial model specification was determined theoretically. Preliminary analyses using the linear "sem" command and "estat mindices" to report modification indices suggested model fit would be improved by adding a path between Current Events Engagement and Engagement Abroad. Because the models contained dichotomous endogenous variables, we chose to use generalized structural equation models rather than linear models for final analyses (Muthén, 1984), using the "gsem" command with robust standard errors. We used the "logit" command to estimate logistic regressions for equations with dichotomous outcomes. Stata does not calculate absolute goodness-of-fit statistics for generalized structural equation models (e.g., RMSEA, TFI, CFI), so we do not report those in discussing the results from each model below. However, we did use Stata's "estat ic" command to compare two versions of the model for each outcome, based on their Akaike Information Criterion (AIC) and Bayesian Information Criterion (BIC) values: one model that contained the path between Current Events Engagement and Engagement Abroad, as suggested by preliminary linear model analyses, and one model that did not (our original theoretical specification). For Cognitive - Knowing, the model containing the path between Current Events Engagement and Engagement Abroad had smaller AIC and BIC values, indicating better comparative fit (AIC = -3.996, BIC = -0.663). Among the models for the other three dimensions, the AIC was smaller but the BIC was slightly larger when the path between Current Events Engagement and Engagement Abroad was included (for Cognitive - Knowledge: AIC $=-3.149$, BIC $=0.183$; Intrapersonal Identity: $\mathrm{AIC}=-1.623, \mathrm{BIC}=1.710$; Interpersonal - Social Responsibility: $\mathrm{AIC}=-3.292, \mathrm{BIC}=$ 0.041). As Vreize (2012) notes, "If the true model is assumed to be complex, with large, moderate, and small effects, and the candidate models oversimplifications, then the AIC may be preferred to the BIC" (p. 241), which is arguably the case for any models of learning and development such as ours. For this reason, and for the sake of consistency among the models, we chose to include the path between Current Events Engagement and Engagement Abroad in all four models (as reflected in Figure 1). 
Figure 1. Conceptual model with hypothesized relationships.

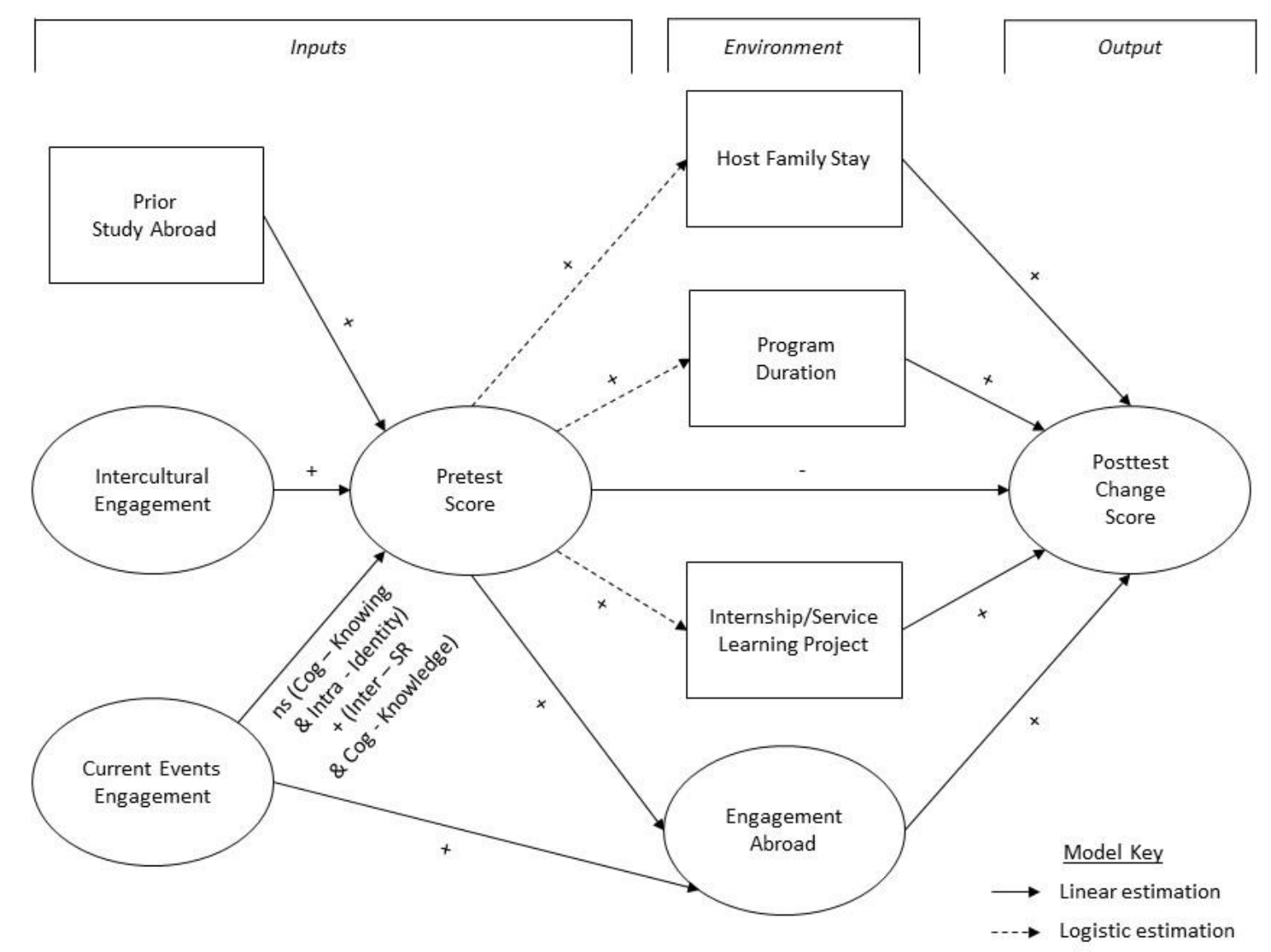

\section{Results}

Prior to running structural equation models, we examined sample mean scores at pre-test and post-test, and for pre-test to post-test change for each of the four global perspective scales of interest (Cognitive - Knowing, Cognitive - Knowledge, Intrapersonal - Identity, and Interpersonal Social Responsibility). These are reported in Table 3. Like Braskamp et al. (2014), we found that mean change scores differed among the four dimensions, and the largest mean magnitude of change was for Cognitive - Knowledge at 0.33 (scores were measured on a five-point scale). Mean change for Cognitive - Epistemology was 0.12 , and for both Intrapersonal - Identity and Interpersonal Social Responsibility, mean change was 0.06 . We then ran a structural equation model for each of the four outcomes, and we report the results of these analyses next. 
Figure 2. Generalized structural equation model for Cognitive - Knowing.

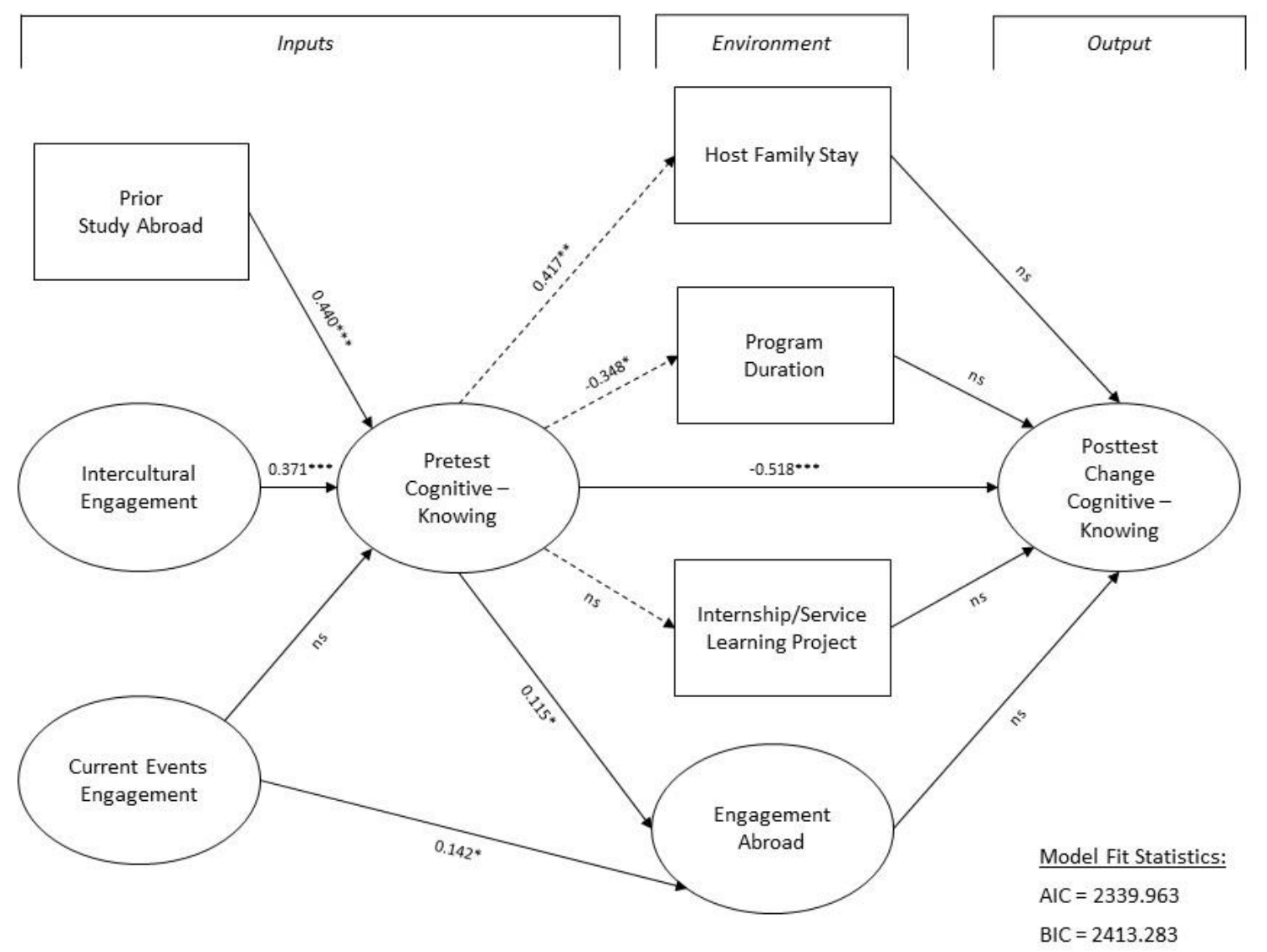

Results by Model

Figure 2 presents the structural equation model with direct path coefficients for the Cognitive Knowing outcome, and Table 5 reports direct, indirect, and total effects. As hypothesized, prior study abroad $(B=0.440, p<.001)$ and Intercultural Engagement $(B=0.371, p<.001)$ positively predicted participants' pre-test scores on this dimension, while Current Events Engagement had no effect. Contrary to our hypotheses, the four education abroad program elements (host family stay, program duration, participating in an internship or service-learning project, and Engagement Abroad) had no statistically significant effects on participants' pre-test to post-test change scores on the dimension of Cognitive - Knowing. However, for two of these program elements, host family stay and Engagement Abroad, students' pre-test scores are positively predictive (host family stay: B $=0.417, p<.01$; Engagement Abroad: $\mathrm{B}=0.115, p<.05)$. This finding suggests that students with higher Cognitive - Knowing scores at pre-test are somewhat more likely to stay with a host family and participate in experiences that allow them to engage more deeply while abroad. We found an inverse relationship between pre-test Cognitive - Knowing score and program duration, indicating that students with higher pre-test scores are slightly less likely to participate in programs that are at least one term in duration ( $\mathrm{B}=-0.348, p<.05)$. Finally, we found a positive direct effect of Current Events Engagement on Engagement Abroad $(B=0.142, p<.05)$, suggesting that students who are interested in news and current events prior to studying abroad are more likely to participate in 
experiences promoting deeper engagement while abroad, independent of their Cognitive - Knowing pre-test score.

Table 5. Direct, indirect, and total effects for Cognitive - Knowing generalized structural equation model.

\begin{tabular}{|c|c|c|c|c|c|c|}
\hline $\begin{array}{l}\text { Structural Path } \\
\text { Prior study abroad } \rightarrow\end{array}$ & \multicolumn{2}{|c|}{ Direct Effect } & \multicolumn{2}{|c|}{$\begin{array}{l}\text { Total Indirect } \\
\text { Effects }\end{array}$} & \multicolumn{2}{|c|}{ Total Effects } \\
\hline Pre-test score & 0.440 & $* * *$ & - & & 0.440 & $* * *$ \\
\hline Host family stay & - & & 0.184 & $*$ & 0.184 & $*$ \\
\hline Program duration & - & & -0.153 & & -0.153 & \\
\hline Internship/service-learning project & - & & 0.098 & & 0.098 & \\
\hline Engagement Abroad & - & & 0.051 & $*$ & 0.051 & $*$ \\
\hline Post-test change score & - & & -0.242 & $* *$ & -0.242 & $* *$ \\
\hline \multicolumn{7}{|l|}{ Intercultural Engagement $\rightarrow$} \\
\hline Pre-test score & 0.371 & $* * *$ & - & & 0.371 & $* * *$ \\
\hline Host family stay & - & & 0.155 & $*$ & 0.155 & $*$ \\
\hline Program duration & - & & -0.129 & & -0.129 & \\
\hline Internship/service-learning project & - & & 0.083 & & 0.083 & \\
\hline Engagement Abroad & - & & 0.043 & $*$ & 0.043 & $*$ \\
\hline Post-test change score & - & & -0.204 & $* * *$ & -0.204 & $* * *$ \\
\hline \multicolumn{7}{|l|}{ Current Events Engagement $\rightarrow$} \\
\hline Pre-test score & 0.047 & & - & & 0.047 & \\
\hline Host family stay & - & & 0.020 & & 0.020 & \\
\hline Program duration & - & & -0.017 & & -0.017 & \\
\hline Internship/service-learning project & - & & 0.011 & & 0.011 & \\
\hline Engagement Abroad & 0.142 & $*$ & 0.005 & & 0.148 & $* *$ \\
\hline Post-test change score & - & & -0.004 & & -0.004 & \\
\hline \multicolumn{7}{|l|}{ Pre-test score $\rightarrow$} \\
\hline Host family stay & 0.417 & $* *$ & - & & 0.417 & $* *$ \\
\hline Program duration & -0.348 & $*$ & - & & -0.348 & $*$ \\
\hline Internship/service-learning project & 0.223 & & - & & 0.223 & \\
\hline Engagement Abroad & 0.115 & $*$ & - & & 0.115 & $*$ \\
\hline Post-test change score & -0.518 & $* * *$ & -0.031 & & -0.549 & $* * *$ \\
\hline
\end{tabular}

$* p<.05, * * p<.01, * * * p<.001$ 
Table 5 continued

\begin{tabular}{|c|c|c|c|}
\hline Structural Path & $\begin{array}{l}\text { Direct } \\
\text { Effect }\end{array}$ & $\begin{array}{l}\text { Total Indirect } \\
\text { Effects }\end{array}$ & $\begin{array}{l}\text { Total } \\
\text { Effects }\end{array}$ \\
\hline \multicolumn{4}{|l|}{ Host family stay $\rightarrow$} \\
\hline Post-test change score & 0.021 & - & 0.021 \\
\hline \multicolumn{4}{|l|}{ Program duration $\rightarrow$} \\
\hline Post-test change score & 0.066 & - & 0.066 \\
\hline \multicolumn{4}{|c|}{ Internship/service-learning project $\rightarrow$} \\
\hline Post-test change score & -0.158 & - & -0.158 \\
\hline \multicolumn{4}{|l|}{ Engagement Abroad $\rightarrow$} \\
\hline Post-test change score & 0.154 & - & 0.154 \\
\hline
\end{tabular}

$* p<.05, * * p<.01, * * * p<.001$

Results of the structural equation model for the Cognitive - Knowledge outcome are presented in Figure 3 (path coefficients) and Table 6 (direct, indirect, and total effects). As with the results for Cognitive - Knowing, both prior study abroad $(\mathrm{B}=0.344, p<.01)$ and Intercultural Engagement (B $=0.282, p<.001)$ positively predicted pre-test scores for Cognitive - Knowledge. Unlike the previous outcome, however, Current Events Engagement also predicted Cognitive - Knowledge pre-test scores $(\mathrm{B}=0.545, p<.001)$. Contrary to our hypothesis, we did not find any statistically significant relationships between participants' Cognitive - Knowledge pre-test scores and the four education abroad program elements (host family stay, program duration, participating in an internship or service-learning project, and Engagement Abroad). Additionally, of the four education abroad program elements, only Engagement Abroad had a statistically significant effect on participants' pre-test to post-test change scores on the Cognitive - Knowledge dimension $(\mathrm{B}=$ 0.254, $p<.05)$. We found a positive direct effect of Current Events Engagement on Engagement Abroad $(\mathrm{B}=0.152, p<.05)$, as we did for Cognitive - Knowing. 
Tara D. Hudson \& Rachel Tomás Morgan

Figure 3. Generalized structural equation model for Cognitive - Knowledge.

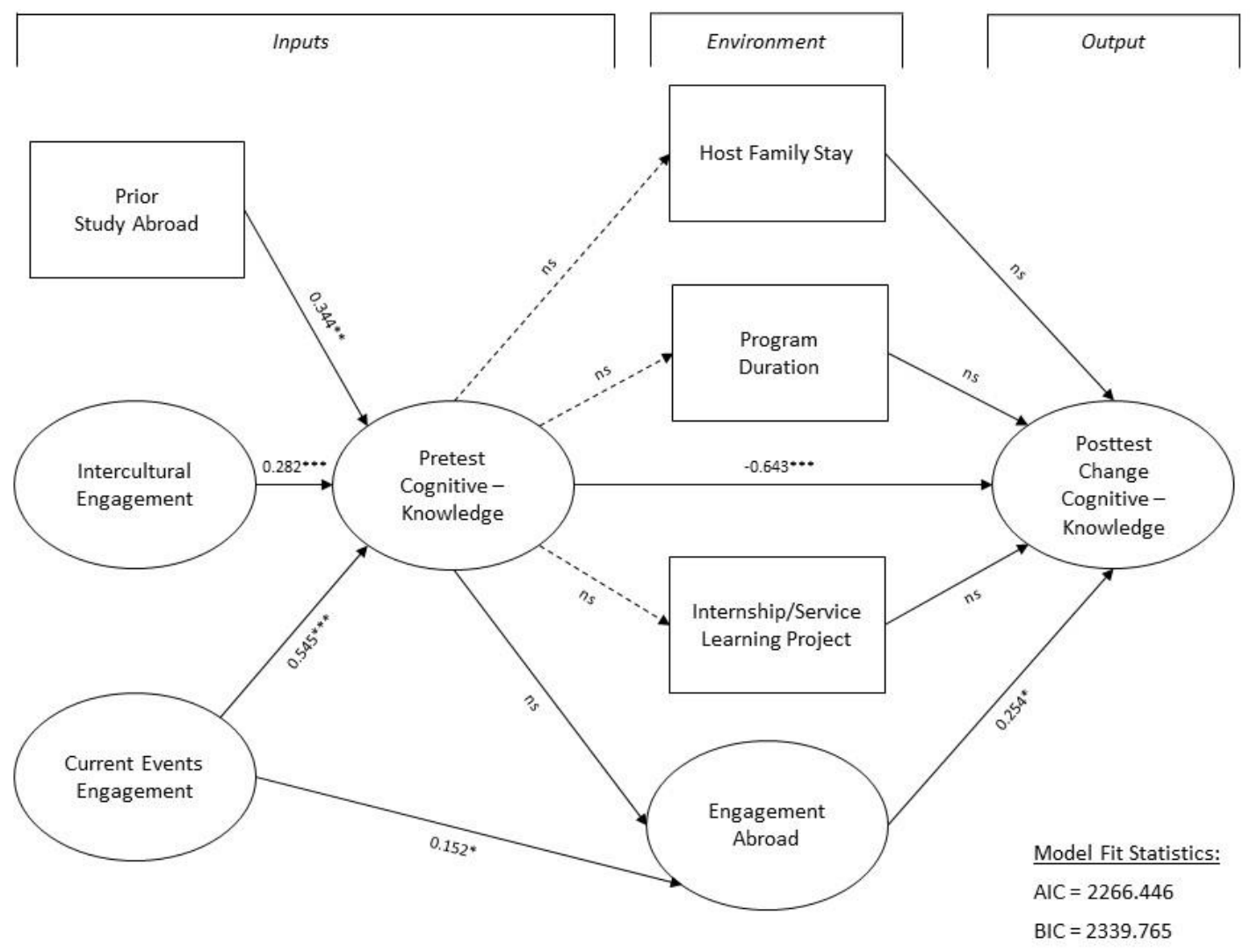


Table 6. Direct, indirect, and total effects for Cognitive - Knowledge generalized structural equation model.

\begin{tabular}{|c|c|c|c|c|c|c|}
\hline \multirow{2}{*}{$\begin{array}{l}\text { Structural Path } \\
\text { Prior study abroad } \rightarrow\end{array}$} & \multicolumn{2}{|c|}{ Direct Effect } & \multicolumn{2}{|c|}{$\begin{array}{l}\text { Total Indirect } \\
\text { Effects }\end{array}$} & \multicolumn{2}{|c|}{ Total Effects } \\
\hline & & & & & & \\
\hline Pre-test score & 0.344 & $* *$ & - & & 0.344 & $* *$ \\
\hline Host family stay & - & & 0.080 & & 0.080 & \\
\hline Program duration & - & & -0.054 & & -0.054 & \\
\hline Internship/service-learning project & - & & -0.021 & & -0.021 & \\
\hline Engagement Abroad & - & & 0.003 & & 0.003 & \\
\hline Post-test change score & - & & -0.218 & $* *$ & -0.218 & $* *$ \\
\hline \multicolumn{7}{|l|}{ Intercultural Engagement $\rightarrow$} \\
\hline Pre-test score & 0.282 & $* * *$ & - & & 0.282 & $* * *$ \\
\hline Host family stay & - & & 0.066 & & 0.066 & \\
\hline Program duration & - & & -0.044 & & -0.044 & \\
\hline Internship/service-learning project & - & & -0.018 & & -0.018 & \\
\hline Engagement Abroad & - & & 0.003 & & 0.003 & \\
\hline \multirow[t]{2}{*}{ Post-test change score } & - & & -0.179 & $* *$ & -0.179 & $* *$ \\
\hline & & & & & 0.066 & \\
\hline \multicolumn{7}{|l|}{ Current Events Engagement $\rightarrow$} \\
\hline Pre-test score & 0.545 & $* * *$ & - & & 0.545 & $* * *$ \\
\hline Host family stay & - & & 0.127 & & 0.127 & \\
\hline Program duration & - & & -0.085 & & -0.085 & \\
\hline Internship/service-learning project & - & & -0.034 & & -0.034 & \\
\hline Engagement Abroad & 0.152 & $*$ & 0.005 & & 0.157 & $* *$ \\
\hline Post-test change score & - & & -0.308 & $* * *$ & -0.308 & $* * *$ \\
\hline \multicolumn{7}{|l|}{ Pre-test score $\rightarrow$} \\
\hline Host family stay & 0.233 & & - & & 0.233 & \\
\hline Program duration & -0.157 & & - & & -0.157 & \\
\hline Internship/service-learning project & -0.062 & & - & & -0.062 & \\
\hline Engagement Abroad & 0.009 & & - & & 0.009 & \\
\hline Post-test change score & -0.643 & $* * *$ & 0.007 & & -0.635 & $* * *$ \\
\hline
\end{tabular}

$* p<.05, * * p<.01, * * * p<.001$ 
Table 6 continued

\begin{tabular}{|c|c|c|c|c|c|}
\hline Structural Path & $\begin{array}{l}\text { Direct } \\
\text { Effect }\end{array}$ & & $\begin{array}{l}\text { Total Indirect } \\
\text { Effects }\end{array}$ & $\begin{array}{l}\text { Total } \\
\text { Effects }\end{array}$ & \\
\hline \multicolumn{6}{|l|}{ Host family stay $\rightarrow$} \\
\hline Post-test change score & 0.125 & & - & 0.125 & \\
\hline \multicolumn{6}{|l|}{ Program duration $\rightarrow$} \\
\hline Post-test change score & 0.159 & & - & 0.159 & \\
\hline \multicolumn{6}{|c|}{ Internship/service-learning project $\rightarrow$} \\
\hline Post-test change score & -0.012 & & - & -0.012 & \\
\hline \multicolumn{6}{|l|}{ Engagement Abroad $\rightarrow$} \\
\hline Post-test change score & 0.254 & $*$ & - & 0.254 & $*$ \\
\hline
\end{tabular}

$* p<.05, * * p<.01, * * * p<.001$

Figure 4 presents the structural equation model with direct path coefficients for the Intrapersonal - Identity outcome, and Table 7 reports direct, indirect, and total effects. Contrary to our hypothesis, prior study abroad did not predict pre-test scores for this outcome, while Current Events Engagement did $(\mathrm{B}=0.214, p<.05)$. Intercultural Engagement also predicted pre-test score $(\mathrm{B}=0.356, p<.001)$, consistent with our hypothesis. Intrapersonal - Identity pre-test score positively predicted participation in an internship or service-learning project $(\mathrm{B}=0.341, p<.05)$ and Engagement Abroad $(B=0.166, p<.001)$, as hypothesized. However, pre-test score was not related to host family stay, and it negatively predicted program duration $(\mathrm{B}=-0.666, p<.001)$, as we also found for the Cognitive - Knowing model. Only two of the four education abroad program elements predicted change scores for Intrapersonal - Identity: program duration $(\mathrm{B}=0.527, p<$ $.001)$ and Engagement Abroad $(B=0.306, p<.001)$. Neither host family stay nor participating in an internship or service-learning project predicted change scores for Intrapersonal - Identity, contrary to our hypothesis. As with the previous models, we found a positive relationship between Current Events Engagement and Engagement Abroad (B $=0.111, p<.05)$. 
Figure 4. Generalized structural equation model for Intrapersonal - Identity.

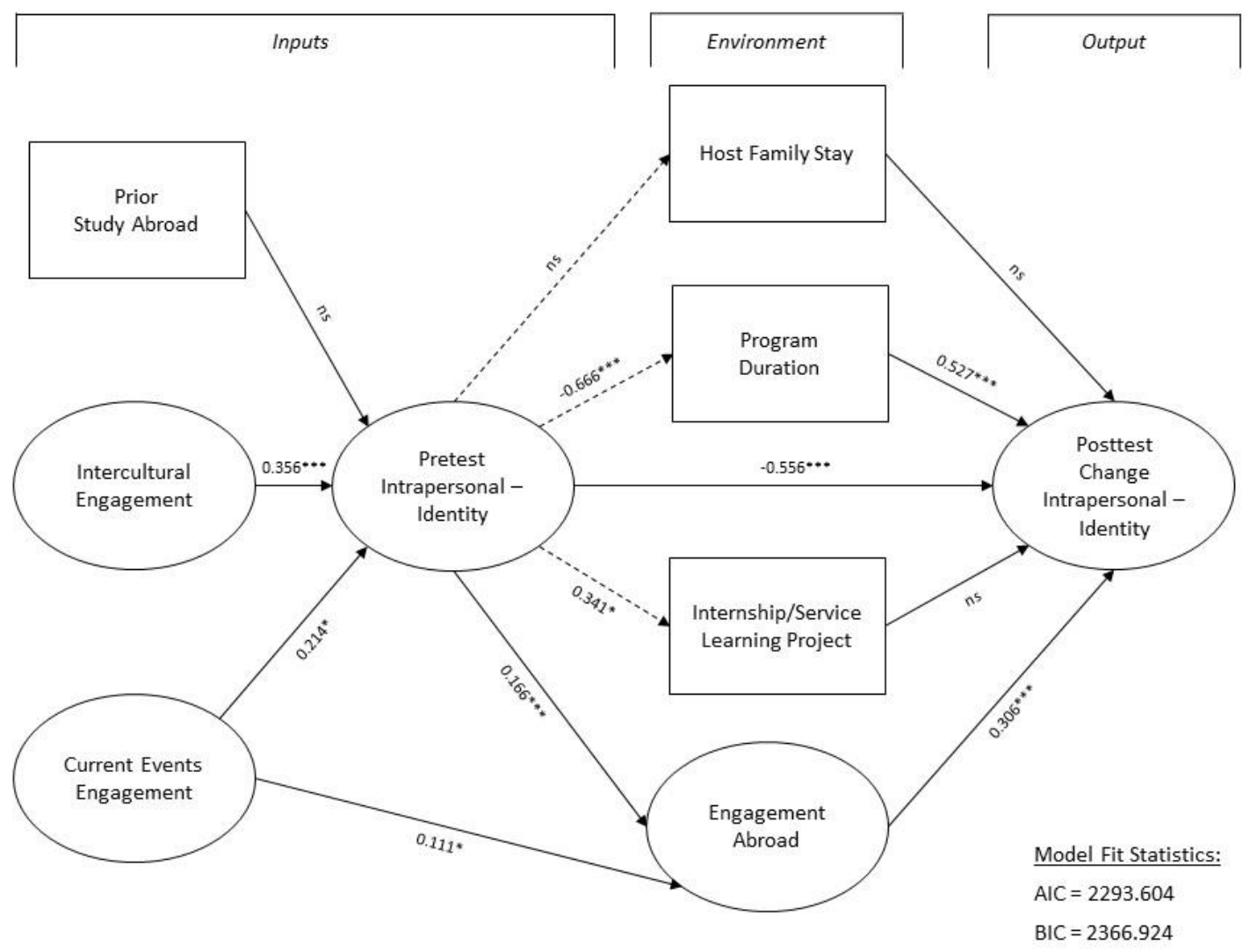


Tara D. Hudson \& Rachel Tomás Morgan

Table 7. Direct, indirect, and total effects for Intrapersonal - Identity generalized structural equation model.

\begin{tabular}{|c|c|c|c|c|c|c|}
\hline \multirow{2}{*}{$\begin{array}{l}\text { Structural Path } \\
\text { Prior study abroad } \rightarrow\end{array}$} & \multicolumn{2}{|c|}{ Direct Effect } & \multicolumn{2}{|c|}{$\begin{array}{l}\text { Total Indirect } \\
\text { Effects }\end{array}$} & \multicolumn{2}{|c|}{ Total Effects } \\
\hline & & & & & & \\
\hline Pre-test score & 0.186 & & - & & 0.186 & \\
\hline Host family stay & - & & 0.017 & & 0.017 & \\
\hline Program duration & - & & -0.124 & & -0.124 & \\
\hline Internship/service-learning project & - & & 0.064 & & 0.064 & \\
\hline Engagement Abroad & - & & 0.031 & & 0.031 & \\
\hline Post-test change score & - & & -0.150 & & -0.150 & \\
\hline \multicolumn{7}{|l|}{ Intercultural Engagement $\rightarrow$} \\
\hline Pre-test score & 0.356 & $* * *$ & - & & 0.356 & $* * *$ \\
\hline Host family stay & - & & 0.032 & & 0.032 & \\
\hline Program duration & - & & -0.237 & $* *$ & -0.237 & $* *$ \\
\hline Internship/service-learning project & - & & 0.121 & & 0.121 & \\
\hline Engagement Abroad & - & & 0.059 & $*$ & 0.059 & $*$ \\
\hline Post-test change score & - & & -0.287 & $* * *$ & -0.287 & $* * *$ \\
\hline \multicolumn{7}{|l|}{ Current Events Engagement $\rightarrow$} \\
\hline Pre-test score & 0.214 & $*$ & - & & 0.214 & $*$ \\
\hline Host family stay & - & & 0.019 & & 0.019 & \\
\hline Program duration & - & & -0.142 & $*$ & -0.142 & $*$ \\
\hline Internship/service-learning project & - & & 0.073 & & 0.073 & \\
\hline Engagement Abroad & 0.111 & $*$ & 0.035 & $*$ & 0.146 & $* *$ \\
\hline Post-test change score & - & & -0.138 & & -0.138 & \\
\hline \multicolumn{7}{|l|}{ Pre-test score $\rightarrow$} \\
\hline Host family stay & 0.091 & & - & & 0.091 & \\
\hline Program duration & -0.666 & $* * *$ & - & & -0.666 & $* * *$ \\
\hline Internship/service-learning project & 0.341 & $*$ & - & & 0.341 & $*$ \\
\hline Engagement Abroad & 0.166 & $* * *$ & - & & 0.166 & $* * *$ \\
\hline Post-test change score & -0.556 & $* * *$ & -0.250 & $*$ & -0.807 & $* * *$ \\
\hline
\end{tabular}

$* p<.05, * * p<.01, * * * p<.001$ 
Table 7 continued

\begin{tabular}{|c|c|c|c|c|c|}
\hline Structural Path & $\begin{array}{l}\text { Direct } \\
\text { Effect }\end{array}$ & & $\begin{array}{l}\text { Total Indirect } \\
\text { Effects }\end{array}$ & $\begin{array}{l}\text { Total } \\
\text { Effects }\end{array}$ & \\
\hline \multicolumn{6}{|l|}{ Host family stay $\rightarrow$} \\
\hline Post-test change score & 0.090 & & - & 0.090 & \\
\hline \multicolumn{6}{|l|}{ Program duration $\rightarrow$} \\
\hline Post-test change score & 0.527 & $* * *$ & - & 0.527 & $* * *$ \\
\hline \multicolumn{6}{|c|}{ Internship/service-learning project $\rightarrow$} \\
\hline Post-test change score & 0.122 & & - & 0.122 & \\
\hline \multicolumn{6}{|l|}{ Engagement Abroad $\rightarrow$} \\
\hline Post-test change score & 0.306 & $* *$ & - & 0.306 & $* * *$ \\
\hline
\end{tabular}

$* p<.05, * * p<.01, * * * p<.001$

Results of the structural equation model for the Interpersonal - Social Responsibility outcome are presented in Figure 5 (path coefficients) and Table 8 (direct, indirect, and total effects). We found prior study abroad $(B=0.353, p<.05)$ and Intercultural Engagement $(B=0.395, p<.001)$ to positively predict participants' pre-test scores, as hypothesized; however, Current Events Engagement had a non-significant effect, contrary to our hypothesis. Also consistent with our hypotheses, we found that pre-test Interpersonal - Social Responsibility score positively predicted Engagement Abroad $(B=0.263, p<.001)$ and participation in an internship or service-learning project while abroad $(\mathrm{B}=0.471, p<.01)$. However, contrary to our hypotheses, pre-test score on this dimension had a non-significant effect on host family stay, and it negatively predicted program duration $(\mathrm{B}=-0.725, p<.001)$, as we also found for Cognitive - Knowing and Intrapersonal Identity pre-test scores. We found non-significant effects for two of the four education abroad program elements (host family stay and participating in an internship or service-learning project) on pre-test to post-test change scores on the Interpersonal - Social Responsibility dimension of global perspective. However, we did find positive effects for program duration $(\mathrm{B}=0.288, p<.05)$ and Engagement Abroad ( $B=0.207, p<.05)$, as hypothesized. Finally, we found a positive direct effect of Current Events Engagement on Engagement Abroad $(B=0.125, p<.05)$, as we found for the previous three outcomes as well. 
Figure 5. Generalized structural equation model for Interpersonal - Social Responsibility.

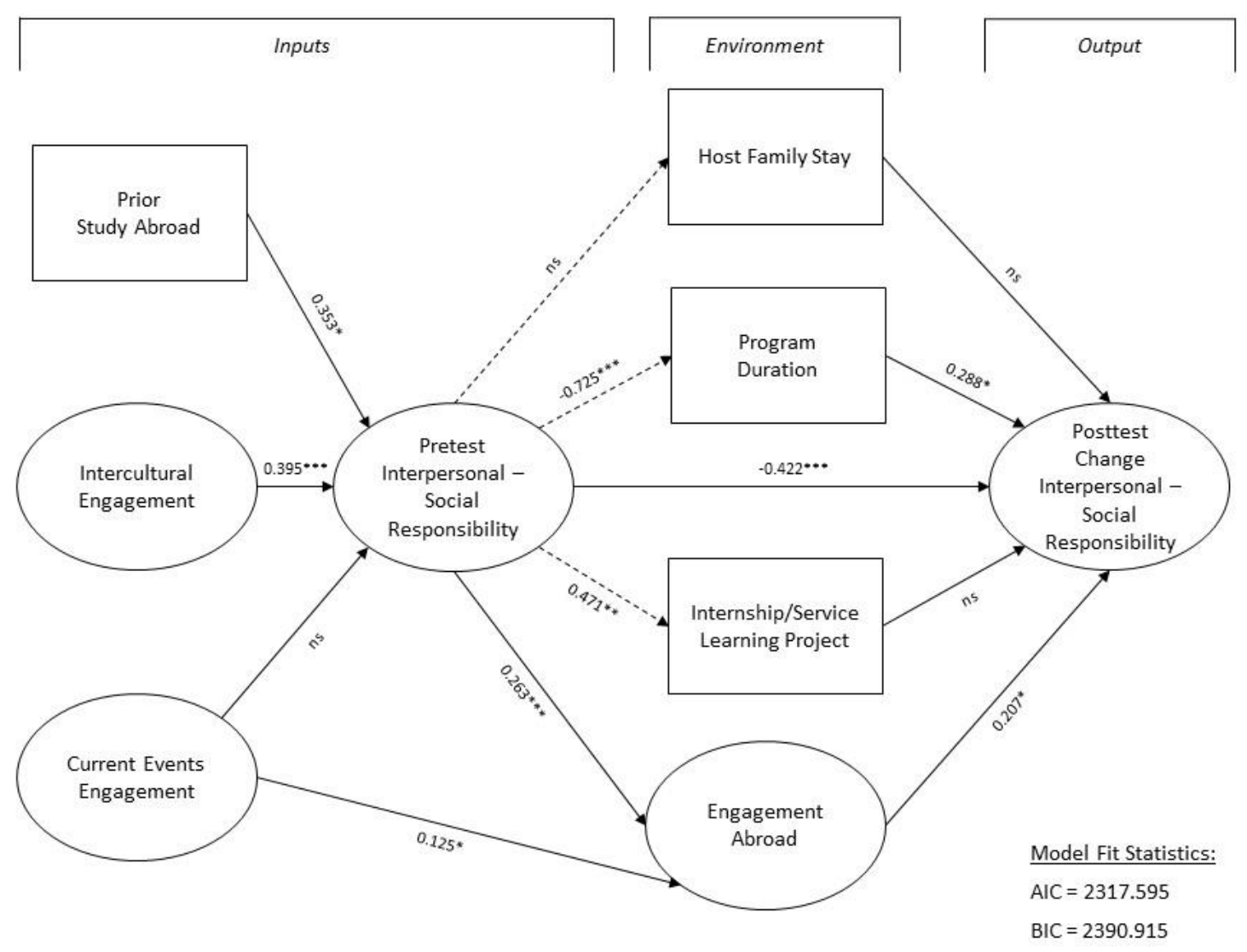

For all four outcomes, participants' pre-test scores were negatively predictive of their post-test change scores, as hypothesized (Cognitive - Knowing: $\mathrm{B}=-0.518$; Cognitive - Knowledge: $\mathrm{B}=-$ 0.643; Intrapersonal - Identity: $\mathrm{B}=-0.556$; Interpersonal - Social Responsibility: $\mathrm{B}=-0.422$; all direct effects significant at the $p<.001$ level). Students who had the lowest scores at pre-test had the greatest room for growth and therefore likely gleaned the greatest development benefits from studying abroad, whereas students who scored highly at pre-test had less room for growth (i.e., a ceiling effect) and therefore showed little change after their education abroad experiences. 
Table 8. Direct, indirect, and total effects for Interpersonal - Social Responsibility generalized structural equation model.

\begin{tabular}{|c|c|c|c|c|c|c|}
\hline \multirow{2}{*}{$\begin{array}{l}\text { Structural Path } \\
\text { Prior study abroad } \rightarrow\end{array}$} & \multicolumn{2}{|c|}{ Direct Effect } & \multicolumn{2}{|c|}{$\begin{array}{l}\text { Total Indirect } \\
\text { Effects }\end{array}$} & \multicolumn{2}{|c|}{ Total Effects } \\
\hline & & & & & & \\
\hline Pre-test score & 0.353 & $*$ & - & & 0.353 & $*$ \\
\hline Host family stay & - & & 0.073 & & 0.073 & \\
\hline Program duration & - & & -0.256 & $*$ & -0.256 & $*$ \\
\hline Internship/service-learning project & - & & 0.166 & & 0.166 & \\
\hline Engagement Abroad & - & & 0.093 & $*$ & 0.093 & $*$ \\
\hline Post-test change score & - & & -0.177 & $*$ & -0.177 & $*$ \\
\hline \multicolumn{7}{|l|}{ Intercultural Engagement $\rightarrow$} \\
\hline Pre-test score & 0.395 & $* * *$ & - & & 0.395 & $* * *$ \\
\hline Host family stay & - & & 0.081 & & 0.081 & \\
\hline Program duration & - & & -0.286 & $* *$ & -0.286 & $* *$ \\
\hline Internship/service-learning project & - & & 0.186 & $*$ & 0.186 & $*$ \\
\hline Engagement Abroad & - & & 0.104 & $* * *$ & 0.104 & $* * *$ \\
\hline Post-test change score & - & & -0.198 & $* * *$ & -0.198 & $* * *$ \\
\hline \multicolumn{7}{|l|}{ Current Events Engagement $\rightarrow$} \\
\hline Pre-test score & 0.043 & & - & & 0.043 & \\
\hline Host family stay & - & & 0.009 & & 0.009 & \\
\hline Program duration & - & & -0.031 & & -0.031 & \\
\hline Internship/service-learning project & - & & 0.020 & & 0.020 & \\
\hline Engagement Abroad & 0.125 & $*$ & 0.011 & & 0.136 & $*$ \\
\hline Post-test change score & - & & 0.004 & & 0.004 & \\
\hline \multicolumn{7}{|l|}{ Pre-test score $\rightarrow$} \\
\hline Host family stay & 0.205 & & - & & 0.205 & \\
\hline Program duration & -0.725 & $* * *$ & - & & -0.725 & $* * *$ \\
\hline Internship/service-learning project & 0.471 & $* *$ & - & & 0.471 & $* *$ \\
\hline Engagement Abroad & 0.263 & $* * *$ & - & & 0.263 & $* * *$ \\
\hline Post-test change score & -0.422 & $* * *$ & -0.080 & & -0.502 & $* * *$ \\
\hline
\end{tabular}

$* p<.05, * * p<.01, * * * p<.001$ 
Table 8 continued

\begin{tabular}{|c|c|c|c|c|}
\hline Structural Path & Direct Effect & $\begin{array}{l}\text { Total Indirect } \\
\text { Effects }\end{array}$ & Total $\mathrm{F}$ & \\
\hline \multicolumn{5}{|l|}{ Host family stay $\rightarrow$} \\
\hline Post-test change score & 0.175 & - & 0.175 & \\
\hline \multicolumn{5}{|l|}{ Program duration $\rightarrow$} \\
\hline Post-test change score & 0.288 & - & 0.288 & $*$ \\
\hline \multicolumn{5}{|c|}{ Internship/service-learning project $\rightarrow$} \\
\hline Post-test change score & 0.082 & - & 0.082 & \\
\hline \multicolumn{5}{|l|}{ Engagement Abroad $\rightarrow$} \\
\hline Post-test change score & 0.207 & - & 0.207 & $*$ \\
\hline
\end{tabular}

\section{Synthesizing Results across Models}

Returning to our hypotheses (see Figure 1), we found Intercultural Engagement to positively predict pre-test scores across all four models, as we had hypothesized. Prior study abroad positively predicted pre-test scores, as hypothesized, for three of the four outcomes (excepting Intrapersonal Identity). Our hypothesized relationships between Current Events Engagement and pre-test scores held for the two Cognitive outcomes, but the relationships were contrary to our hypothesis for Intrapersonal - Identity and Interpersonal - Social Responsibility.

The relationships between pre-test scores and the four education abroad program elements, all of which we had hypothesized to be positive, varied widely. For host family stay, we found only one positive relationship (Cognitive - Knowing). For program duration, we did not find positive relationships with pre-test scores in any of the models, and in fact found negative relationships in three of the models (Cognitive - Knowing, Intrapersonal - Identity, and Interpersonal - Social Responsibility). Because the equations estimating the relationships between pre-test score and the three dichotomous education abroad program elements were logistic regressions, the coefficients for these paths cannot be interpreted directly or compared in magnitude to the coefficients for the linear paths. Additional calculations performed by the researchers revealed that each one standard deviation unit increase in Interpersonal - Social Responsibility pre-test score leads to about an 18\% decrease in the probability of that student enrolling in an education abroad program of one term or longer; for Intrapersonal - Identity, the corresponding probability was about $-16 \%$ and for Cognitive - Knowing, nearly -9\%. Pre-test scores positively predicted participation in an internship or servicelearning project in two of the models (Intrapersonal - Identity and Interpersonal - Social Responsibility) and positively predicted Engagement Abroad in three of the models (excepting Cognitive - Knowledge).

The relationships between the four education abroad program elements and pre-test to posttest change scores on the four global perspective dimensions also varied: Both host family stay and participation in an internship or service-learning project had no effect on change scores in any of the four models. Program duration positively predicted change scores in only two models 
(Intrapersonal - Identity and Interpersonal - Social Responsibility), while Engagement Abroad predicted change scores in three of the four models (excepting Cognitive - Knowing). Finally, the relationship between Current Events Engagements and Engagement Abroad was positive for all four models, as hypothesized.

\section{Discussion}

The purpose of this study was to understand the relationships between features of education abroad programs — specifically, program duration and the extent of students' engagement in learning and with local communities while abroad - with participants' growth on four dimensions of global perspective: two cognitive dimensions (Knowing and Knowledge), one intrapersonal dimension (Identity), and one interpersonal dimension (Social Responsibility). Reflecting upon our results across the four models, we believe that the ceiling effect may explain why we found in many cases (although not consistently) that three of the four study abroad program elements (host family stay, program length, and participating in an internship or service-learning project) had nonsignificant effects on participants' pre-test to post-test change scores. As Vande Berg, Connor-Linton, \& Paige (2009) also found in their study of study abroad "program learning interventions" (e.g., program duration, host family stay) and intercultural learning, "[students] who had the most to gain, did so" (p. 23) regardless of most interventions.

Alternatively, the timing of when we administered the post-test may also explain the lack of growth. Others have found that students' learning plateaus or even regresses at re-entry; when cultural mentoring continues through the re-entry process, learning gains begin to appear (Rexeisen, 2013; Vande Berg, Paige, \& Lou, 2012). Another intriguing possibility, proposed by Hartman, Vandermaas-Peeler, and Edwards (2017), is that decreases in pre-test to post-test scores on measures of global learning may occur for students who have previously engaged in community-based learning or service learning in domestic settings. Students who have these prior domestic engagement experiences enter their experiences abroad with certain expectations and assumptions regarding engaged learning, only to have these expectations and assumptions disrupted in a new, unfamiliar context, resulting in temporary regressions on measures of learning. In contrast, students who have not previously participated in domestic engagement experiences do not experience the same level of cognitive disruption because they have fewer expectations and assumptions going into their experiences abroad. Indeed, Hartman et al. suggest that pre-test to post-test regression may, in fact, be a positive indicator of deep learning resulting from well-designed high-impact practices. More research is needed to investigate this possible explanation for pre-test to post-test score decreases.

Although none of the models found statistically significant effects for two of the four program elements (host family stay and participation in an internship or service-learning project) on students' pre-test to post-test change on any of the four dimensions of global perspective, we did find program duration to have a positive effect on change scores for two dimensions: Intrapersonal Identity and Interpersonal - Social Responsibility. Compared to students who were abroad for less than one term, participants who completed an education program that is one term or longer showed a pre-test to post-test score increase by nearly three-tenths of a standard deviation on the dimension of Interpersonal - Social Responsibility and more than half of a standard deviation on the dimension of Intrapersonal - Identity, independent of their pre-test scores. Additionally, we found 
that participants' levels of Engagement Abroad (a factor measuring how often participants engaged in certain learning and community interaction experiences while abroad) had a positive effect on students' growth on three dimensions: Cognitive - Knowledge, Intrapersonal - Identity, and Interpersonal - Social Responsibility. Specifically, an increase of one standard deviation in Engagement Abroad led to change score increases of about three-tenths of a standard deviation for Intrapersonal - Identity, a quarter of a standard deviation for Cognitive - Knowledge, and a fifth of a standard deviation for Interpersonal - Social Responsibility. Given how these three dimensions are defined (Merrill et al., 2012; RISE, 2017), it makes sense that the longer and more deeply students are immersed in local communities during their education abroad program, the more growth they will experience in these areas.

Although the primary focus of this research was to examine the relationships between education abroad program design elements and students' growth in global perspective (i.e., how experiences while studying abroad shape outcomes), the I-E-O structural equation modeling approach also enabled us to highlight how certain input factors relate to students' growth in global perspective prior to and after going abroad. We found that having previously studied abroad positively predicted students' pre-test scores in three of the four models, providing additional evidence that education abroad has a positive relationship with Cognitive - Knowing (echoing the finding of Tarrant et al., 2015), Cognitive - Knowledge, and Interpersonal - Social Responsibility dimensions of global perspective, even if specific program elements themselves may not have direct effects on these dimensions. Additionally, three of the four models found that on-campus intercultural engagement has small but statistically significant indirect effects on the extent to which students engage deeply while abroad (as measured by the Engagement Abroad factor; see Tables 47). This finding suggests that on-campus intercultural engagement may prepare students developmentally for deeper engagement with the host country's culture and people while abroad, perhaps by strengthening their actual or perceived intercultural competence. This possible developmental pathway is a fruitful area for future research.

Additionally, our finding that higher pre-test scores on three of the four scales (Cognitive Knowing, Intrapersonal - Identity, and Interpersonal - Social Responsibility) positively predicted Engagement Abroad is congruent with how these three dimensions of global perspective are defined. Because the Cognitive - Knowing dimension of global perspective concerns individuals' recognition of "the importance of cultural context in judging what is important to know and value" (RISE, 2017, p. 8), students who score more highly on this dimension prior to going abroad may be more inclined to choose education abroad experiences that allow for intercultural engagement, possibly due to increased comfort in intercultural situations or because they are more aware of the benefits such experiences may bring for their own personal development. Similarly, students who score more highly on the Intrapersonal - Identity dimension of global perspective, which "assesses being aware of and accepting one's identity and sense of purpose" (RISE, 2017, p. 9), and the Interpersonal - Social Responsibility dimension, which "assesses being interdependent and having social concern for others" (RISE, 2017, p. 10), likely place greater value on the learning that can be gained through engagement with local communities while abroad. In contrast, the Cognitive Knowledge dimension "assesses ones [sic] understanding and awareness of various cultures and their impact on society” (RISE, 2017, p. 8), which may have less connection to students' motivation for or comfort in engaging in the experiences that comprise the Engagement Abroad factor. 
Finally, we offer two possible explanations for our finding of an inverse relationship between participants' pre-test scores and program duration in three of the models (for Cognitive - Knowing, Intrapersonal - Identity, and Interpersonal - Social Responsibility). First, perhaps students who enter their education abroad experience with high scores on these three dimensions feel less motivation to foster their growth in these areas through spending extended time abroad, while students with lower pre-test scores may seek longer experiences abroad in order to maximize their development. Second, this inverse relationship may result from the nature of our sample. As noted in Table 2, about half of the sample (49\%) participated in a summer service-learning education abroad program, a short-term program as defined by the Global Perspective Inventory. However, this subset of participants had much higher pre-test scores on average than the other half of the sample (differences in group means, on a 5-point scale, ranged from a low of 0.14 for Cognitive Knowledge to a high of 0.48 for Interpersonal - Social Responsibility). It is possible that with a different sample the relationship between pre-test scores and program duration might be nonsignificant or even positive.

\section{Limitations}

As noted earlier, the nature of this sample is one limitation of this study. In order to have adequate statistical power for our analyses, we had to combine data from students participating in two very different types of education abroad programs: semester-long programs (in Europe, Chile, and Mexico) and international summer service-learning programs (Latin America: Argentina, Bolivia, Brazil, Ecuador, El Salvador, Guatemala, Honduras, Nicaragua, Peru; Africa: Ghana, Senegal, South Africa, Tanzania, Uganda; and Asia: Bangladesh, Cambodia, India, Nepal). Not only did the experiences abroad differ by program elements, but the characteristics of students who chose to participate in each type of program may have differed as well, beyond the variables measured and included in our analyses. Additionally, we drew our sample from a single institution (a private, religiously affiliated, more selective, medium-sized research university), which may limit the generalizability of our findings to students participating in education abroad at other types of institutions. Finally, the differences in post-test survey items between the 2012 and 2013 versions of the Global Perspective Inventory led us to create an adapted version of the Intrapersonal - Identity scale for analyses and prevented us from including the Intrapersonal - Affect and Interpersonal Social Interactions scales in our analyses, as discussed previously. Therefore, we can only offer conclusions about how participating in education abroad relates to some aspects of college students' development of global perspective, rather than their development of global perspective as a whole.

\section{Significance and Conclusions}

As noted previously, ample evidence suggests that education abroad contributes to important student learning outcomes: intellectual, civic, and personal. These outcomes are valued not just by colleges and universities themselves, in the interest of preparing civic-minded graduates, but by employers as well (Kuh, 2008; Trooboff et al., 2007-2008). Pederson (2010) argues that "if intercultural effectiveness is a goal of study abroad, we need to . . . develop curriculum (regardless of academic content) that incorporates opportunities for such learning and development in students" (p. 77). A similar argument can be made about global perspective; if we as international educators agree that developing students' global perspective is a key learning goal of study abroad, then we need to understand the program elements that facilitate that learning and incorporate those 
as best practices into the design of our study abroad programs. Alternatively, we also need to know which program design features are less effective, or even possibly ineffective, to ensure that the programs we offer to students foster desired learning; it is no longer sufficient, as Vande Berg, Paige, \& Lou (2012) assert, to assume that intercultural learning happens simply though immersion in new environments. Vande Berg, Paige, \& Lou highlight the particular importance of "cultural mentors" intervening throughout the education abroad cycle (pre/during/post) to ensure students learn and develop more effectively and appropriately. Because the number of students participating in shortterm programs has increased in the past decade, from 51\% in 2004-2005 to 63\% in 2014-2015 (Institute of International Education, 2016), designing and delivering programs that include effective programmatic features may help to mitigate the lesser effectiveness of program duration alone.

This study provides additional evidence for the relationship between education abroad and participants' development of global perspective, defined as "the capacity and predisposition for a person to think with complexity taking into account multiple perspectives, to form a unique sense of self that is value based and authentic, and to relate to others with respect and openness especially with those who are not like her" (Braskamp, 2014, quoted in RISE, 2017, p. 3). Rather than comparing the outcomes of students who participate in education abroad with those who do not, this study examined the relationships between four education abroad program elements (host family stay, program duration, participating in an internship or service-learning project, and Engagement Abroad, a factor measuring level of engagement in certain learning and community interaction experiences while abroad) and students' pre-test to post-test growth in global perspective. Using a pre-test/post-test design and structural equation models to account for both direct and indirect effects of relevant variables that might relate to growth in global perspective, we found that participation in a program that was one term or longer (as defined by the survey instrument) and more frequent engagement in deep learning and community interaction experiences while abroad (as measured by the Engagement Abroad factor) had positive relationships with students' pre-test to post-test change on the Interpersonal - Social Responsibility dimension of global perspective, but not on the Cognitive - Knowing dimension. We also found that living with a host family and participation in an internship or service-learning project had no statistically significant effect on students' development on any of the four global perspective dimensions, reflecting earlier findings by Vande Berg, Connor-Linton, \& Paige (2009) and disruption-regression explanation posited by Hartman et al. (2017).

Our findings add further nuance to the debate about the relationship between program duration and student learning; it seems that the relationship may not be uniform across all forms of learning, but rather may differ depending upon the kind of learning being measured. It may, therefore, be too simplistic to assert that longer programs always lead to greater learning (e.g., Hoff, 2008; Kurt et al., 2013; Medina-Lopez-Portillo, 2004), or even that the effect of program duration on learning resembles a U-curve (Heinzmann et al., 2015). Instead, it seems that certain forms of learning may be enhanced by longer sojourns abroad, while other forms of learning can be enhanced by programs of any duration. Regardless, our research provides further evidence that program duration alone does not predict student learning gains, and consequently we agree with Selby (2008) that intentionally structured learning activities are more important than program duration for facilitating student learning. 
Tarozzi and Torres (2016) assert that "a global perspective should always be deeply grounded in local communities: the place where experience makes meaning of abstract knowledge and values" ( $p$. 11). Our findings partially support their assertion, as we found that higher levels of Engagement Abroad (a composite factor that includes forms of engagement with local communities) had a positive effect on participants' growth on the dimension of Interpersonal - Social Responsibility, but not Cognitive - Knowing. However, if our goal as educators is "fostering students' development of personal and social responsibility," as emphasized by the AAC\&U's Core Commitments (O’Neill, 2012, p. 2), designing education abroad programs that facilitate deep learning and community interaction is an effective means of achieving this goal.

\section{References}

Anderson, P. H., \& Lawton, L. (2011). Intercultural development: Study abroad vs. on-campus study. Frontiers: The Interdisciplinary Journal of Study Abroad, 21, 86-108.

Association of American Colleges and Universities (AAC\&U). (2017). On solid ground: VALUE report 2017. Washington, DC: Author. Retrieved from https://www.aacu.org/sites/default/files/files/FINALFORPUBLICATIONRELEASEONSOLIDGRO UND.pdf

Association of American Colleges and Universities (AAC\&U). (n.d.). VALUE rubrics. Washington, DC: Author. Retrieved from https://www.aacu.org/value-rubrics

Astin, A. W. (1993). What matters in college?: Four critical years revisited. San Francisco, CA: JosseyBass.

Bennett, J. M. (2008) On becoming a global soul: A path to engagement during study abroad. In V. Savicki (Ed.), Developing intercultural competence and transformation (pp. 13-31). Sterling, VA: Stylus.

Braskamp, L. A., Braskamp, D. C., \& Engberg, M. E. (2014, August). Global Perspective Inventory (GPI): Its purpose, construction, potential uses, and psychometric characteristics. Chicago, IL: Global Perspective Institute Inc.

Chickering, A., \& Braskamp, L. A. (2009, Fall). Developing a global perspective for personal and social responsibility. Peer Review, 11(4). 27-30.

Deardorff, D. K. (2008). Intercultural competence: A definition, model, and implications for education abroad. In V. Savicki (Ed.), Developing intercultural competence and transformation (pp. 32-52). Sterling, VA: Stylus.

Dixon, B. (2015). International service learning: Analytical review of published research literature. Frontiers: The Interdisciplinary Journal of Study Abroad, 25, 107-131.

Dwyer, M. M. (2004). More is better: The impact of study abroad program duration. Frontiers: The Interdisciplinary Journal of Study Abroad, 10, 151-163.

Engberg, M. E. (2013). The influence of study away experiences on global perspective-taking. Journal of College Student Development, 54(5), 466-480. doi: 10.1353/csd.2013.0073

Engberg, M. E., Davidson, L. M., Manderino, M., \& Jourian, T. J. (2016). Examining the relationship between intercultural engagement and undergraduate students' global perspective. Multicultural Education Review, 8(4), 253-274.

Engberg, M. E., \& Fox, K. (2011). Exploring the relationship between undergraduate service-learning experiences and global perspective-taking. Journal of Student Affairs Research and Practice, 48(1), 85-105.

Engberg, M. E., \& Jourian, T. J. (2015). Intercultural wonderment and study abroad. Frontiers: The Interdisciplinary Journal of Study Abroad, 25, 1-19.

Engberg, M. E., Jourian, T. J., \& Davidson, L. M. (2016). The mediating role of intercultural wonderment: Connecting programmatic components to global outcomes in study abroad. Higher Education, 71(1), 21-37. 
Engle, L., \& Engle, J. (2003). Study abroad levels: Toward a classification of program types. Frontiers: The Interdisciplinary Journal of Study Abroad, 9(1), 1-20.

Fine, J. B., \& McNamara, K. W. (2011). Community redefined: School leaders moving from autonomy to global interdependence through short-term study abroad. Frontiers: The Interdisciplinary Journal of Study Abroad, 21, 254-274.

Gaia, A. C. (2015). Short-term faculty-led study abroad programs enhance cultural exchange and selfawareness. International Education Journal: Comparative Perspectives, 14(1), 21-31.

Global Perspective Institute. (n.d.). Description of Global Perspective Inventory scales. Pella, IA: Author.

Hartman, E., Vandermaas-Peeler, M., \& Edwards, A. (2017, October). Global engagement survey: Assessing intercultural competence, civic engagement, and critical reflection. Presentation at the Association of American Colleges \& Universities (AAC\&U) Global Engagement and Social Responsibility Conference, New Orleans, LA.

Heinzmann, S., Künzle, R., Schallhart, N., \& Müller, M. (2015, Fall). The effect of study abroad on intercultural competence: Results from a longitudinal quasi-experimental study. Frontiers: The Interdisciplinary Journal of Study Abroad, 26, 187-208.

Hoff, J. G. (2008). Growth and transformation outcomes in international education. In V. Savicki (Ed.), Developing intercultural competence and transformation (pp. 53-73). Sterling, VA: Stylus.

Institute of International Education. (2016). Open Doors: Duration of study abroad, 2004/05-2014/15. Retrieved from https://www.iie.org/Research-and-Insights/Open-Doors/Data/US-StudyAbroad/Duration-of-Study-Abroad

Kiely, R. (2004). A chameleon with a complex: Searching for transformation in international servicelearning. Michigan Journal of Community Service Learning, 10(2), 5-20.

Kilgo, C. A., Sheets, J. K. E., \& Pascarella, E. T. (2015). The link between high-impact practices and student learning: Some longitudinal evidence. Higher Education, 69, 509-525. doi: 10.1007/s10734014-9788-z

Kuh, G. D. (2008). High-impact educational practices: What they are, who has access to them, and why they matter. Washington, DC: Association of American Colleges and Universities.

Kurt, M. R., Olitsky, N. H., \& Geis, P. (2013, Fall). Assessing global awareness over short-term study abroad sequence: A factor analysis. Frontiers: The Interdisciplinary Journal of Study Abroad, 23, 2241.

Lott II, J. L. (2013). Predictors of civic values: Understanding student-level and institutional-level effects. Journal of College Student Development, 54(1), 1-16. doi: 10.1353/csd.2013.0002

Medina-Lopez-Portillo, A. (2004). Intercultural learning assessment: The link between program duration and the development of intercultural sensitivity. Frontiers: The Interdisciplinary Journal of Study Abroad, 10, 179-199.

Merrill, K. C., Braskamp, D. C., \& Braskamp, L. A. (2012). Assessing individuals' global perspective. Journal of College Student Development, 53(2), 356-360. doi: 10.1353/csd.2012.0034

Murphy, D., Sahakyan, N., Yong-Yi, D., \& Magnan, S. S. (2014, Fall). The impact of study abroad on the global engagement of university graduates. Frontiers: The Interdisciplinary Journal of Study Abroad, $24,1-24$.

Muthén, B. (1984). A general structural equation model with dichotomous, ordered categorical, and continuous latent variable indicators. Psychometrika, 49(1), 115-132. doi: doi.org/10.1007/BF02294210

National Survey of Student Engagement (NSSE). (2007). Experiences that matter: Enhancing student learning and success. Bloomington, IN: Indiana University Center for Postsecondary Research. Retrieved from http://nsse.iub.edu/NSSE_2007_Annual_Report

O’Neill, N. (2012). Promising practices for personal and social responsibility: Findings from a national research collaborative. Washington, DC: Association of American Colleges and Universities. Retrieved from http://www.aacu.org/sites/default/files/files/core_ commitments/promising_practices_rc2012.pdf 
Pederson, P. J. (2010). Assessing intercultural effectiveness outcomes in a year-long study abroad program. International Journal of Intercultural Relations, 34, 70-80. doi: doi:10.1016/J.IJINTREL.2009.09.003

Research Institute for Studies in Education (2017). Global Perspective Inventory: Theoretical foundations and scale descriptions. Iowa State University: Ames, IA.

Rexeisen, R. J. (2013). Study abroad and the boomerang effect: The end is only the beginning. Frontiers: The Interdisciplinary Journal of Study Abroad, 22, 166-181.

Salisbury, M. H., An, B. P., \& Pascarella, E. T. (2013) The effect of study abroad on intercultural competence among undergraduate college students. Journal of Student Affairs Research and Practice, 50(1), 1-20. doi: 10.1515/jsarp-2013-0001

Selby, R. (2008). Designing transformation in international education. In V. Savicki (Ed.), Developing intercultural competence and transformation (pp. 1-10). Sterling, VA: Stylus.

Stebleton, M. J., Soria, K. M., \& Cherney, B. (2013). The high impact of education abroad: College students' engagement in international experiences and the development of intercultural competencies. Frontiers: The Interdisciplinary Journal of Study Abroad, 22, 1-24.

Sutton, R. C., \& Rubin, D. L. (2004). The GLOSSARI project: Initial findings from a system-wide research initiative on study abroad learning outcomes. Frontiers: The Interdisciplinary Journal of Study Abroad, 10, 65-82.

Tarozzi, M., \& Torres, C. A. (2016). The priority of global citizenship education. In Global citizenship education and the crises of multiculturalism: Comparative perspectives (pp. 1-22). London, UK: Bloomsbury Publishing.

Tarrant, M. A., Rubin, D. L., \& Stoner, L. (2015, Fall). The effects of studying abroad and studying sustainability on students' global perspectives. Frontiers: The Interdisciplinary Journal of Study Abroad, 26, 68-82.

Trooboff, S., Vande Berg, M., \& Rayman, J. (2007-2008, Winter). Employer attitudes toward study abroad. Frontiers: The Interdisciplinary Journal of Study Abroad, 15, 17-33.

Vande Berg, M., Connor-Linton, J., \& Paige, R. M. (2009). The Georgetown Consortium Project: Interventions for student learning abroad. Frontiers: The Interdisciplinary Journal of Study Abroad, $18,1-75$.

Vande Berg, M., Paige, R., \& Lou, K. H. (2012). Student learning abroad: What our students are learning, what they're not, and what we can do about it. Sterling, VA: Stylus.

Vrieze, S. I. (2012). Model selection and psychological theory: A discussion of the differences between the Akaike information criterion (AIC) and the Bayesian information criterion (BIC). Psychological Methods, 17(2), 228-243. doi:10.1037/a0027127. 